Article

\title{
Conceptualization of an Indicator System for Assessing the Sustainability of the Bioeconomy
}

\author{
Vincent Egenolf * and Stefan Bringezu(D) \\ Sustainable Resource Futures Group (SURF), Center for Environmental Systems Research (CESR), \\ University of Kassel, 34121 Kassel, Germany; bringezu@uni-kassel.de \\ * Correspondence: Vincent.egenolf@usf.uni-kassel.de
}

Received: 16 November 2018; Accepted: 11 January 2019; Published: 16 January 2019

check for updates

\begin{abstract}
The increased use of biogenic resources is linked to expectations of "green" economic growth, innovation spurts through biotechnology, development options for rural areas, and an increasingly regenerative resource base that is also climate-neutral. However, for several years the signs for unintentional and unwanted side effects have been increasing. In 2015, the 2030 Agenda for Sustainable Development was published at the international level in order to address this problem and deliver a starting point for a comprehensive sustainability criteria evaluation catalogue. Impact indicators to quantify the environmental burden induced by national activities in foreign countries are especially lacking. In this article a comprehensive framework for the evaluation of the sustainability of the bioeconomy, considering key objectives and relevant criteria for environmental, economic, and social sustainability is developed. A special focus is set to the intersection area of the three pillars of sustainability, where the particularly important integrative key objectives and the indicators assigned to them (e.g., resource footprints) apply. This indicator set can be used as a basis for bio-economy monitoring, which uses and produces differently aggregated information on different levels of action, with a focus at the national level but also including global impacts of domestic production and consumption.
\end{abstract}

Keywords: resource footprints; DPSIR concept; integrative key objectives

\section{Introduction}

The increased use of biogenic resources is linked to expectations of "green" economic growth, innovation spurts through biotechnology, development options for rural areas, and an increasingly regenerative resource base that is also climate-neutral. According to the definition of the "German Bio-economy Council", the bioeconomy comprises "the production and use of biological resources (including knowledge) in order to provide products, processes, and services in all economic sectors within the framework of a sustainable economic system" [1].

In 2010, the German National Research Strategy on Bio-Economy 2030 was released [2]. The focus was on international competitiveness in research and development of biotechnology. In 2014, this framework was extended to become the National Policy Strategy on Bioeconomy and supplemented by industrial and energy policy, agriculture, forestry and fisheries, as well as climate and environmental policy [3]. The main goals were food security, climate protection, sustainable consumption, and environmental protection. A progress report was published in 2016 [4] and an evaluation of the framework in 2017 [5]. A further update, combining research and political strategy, was announced to be published in 2019 [6]. The new main strategy will focus on the sustainable shaping of agricultural and silvicultural production along with innovative and bio-based alternatives to existing production processes. Paying attention to global markets and trading relations as a condition for bioeconomy, cooperation across national borders is seen as another focal point. 
The EU's strategy on bio-economy developed from several predecessor strategies, such as early biotechnology programs (1990s), the Strategy on Biotechnology 2002, and the concept of the Knowledge-Based Bio-Economy [7]. The goal was to tackle the challenge of boosting industrial and economic cooperation, along with the reinforcement of excellence in science and European transnational participation in research projects [7]. The bio-economy strategy of the European Union was under review in 2017 and was updated in 2018 [8-10]. In summary, the five objectives of the European bioeconomy strategy 2012 remained intact. These are: ensuring food and nutrition security, managing natural resources sustainably, reducing dependence on non-renewable, unsustainable resources, whether sourced domestically or from abroad, mitigating and adapting to climate change, and strengthening European competitiveness and creating jobs. The updated European strategy supports these goals by a system-approach action plan, which consists of three main areas. First, to strengthen and scale-up the bio-based sectors [11] and unlock investments and markets. Second, to deploy local bio-economy strategies rapidly across Europe. Third, to understand the ecological boundaries of the bio-economy. Thus, the EU and German bio-economy strategy has many similarities with nuanced variation of foci.

While dedicated policies have been established to foster bio-economy, for several years the signs for unintentional and unwanted side effects are increasing. Globally the agricultural cultivation area is expanding at the expense of natural ecosystems, like tropical rainforests, to feed the growing population and supply them with energy [12-14]. Among other things, this leads to losses of biodiversity [15-17] and to increased greenhouse gas emissions [18-20].

The extended use of agricultural area for the supply of end-energy in Germany offers economic advantages for the agricultural sector and seems to be positive for the climate footprint. However, in a situation of increasing scarcity of arable land worldwide, it is inducing land conversion, especially in the regions of origin of imports to net consuming countries like Germany, which is also contrary to the goals set for climate and resource protection, in the sense of international responsibility [21-23]. The IPCC defines direct land use change (dLUC) as the change of use or management of land area through human impact, which can cause a change in land cover [24]. Indirect land use change (iLUC) refers to change of land use induced by the shift of production quantities or sites in other areas [25].

As a result of globalization, the locations of production and consumption lie further apart [26]. Nevertheless, production and consumption are linked through process and value-added chains $[27,28]$. Producers and consumers can orientate themselves partly through product certification in order to support more sustainable business practices through their demand. However, at this particular point further research is needed, because the labelling is complex and the term "sustainability" is used in different manners for different products [29]. A major problem results from the fact that certification of selected product chains cannot control indirect land use change induced by growing demand for biomass based products [30]. The question arises of how the overall demand of a country for biotic resources has to be evaluated at the macro scale. In more general terms, the question is how the balance of the bioeconomy will turn out if it is evaluated from different perspectives based on comprehensive sustainability criteria.

Research is ongoing to provide the basis for monitoring and assessing the sustainability of the bio-economy in Germany (Project: Systemic Monitoring and Modelling of the Bio-Economy (SYMOBIO), symobio.de and Project: Bio-Economy Pathways and Societal Transformation Strategies (BEPASO)) and the EU [31,32]. FAO has been working with international experts towards sustainable bio-economy guidelines [33] and provided an inventory on how sustainability has been addressed in national bio-economy strategies so far [34].

The 2030 Agenda for Sustainable Development was created at the international level [35] in order to provide harmonized guidance for monitoring the progress for every country. This action plan comprises 17 sustainable development goals (SDGs) [36-38]. Included are topics like "SDG 2: Zero Hunger", "SDG 13: Climate Action", and "SDG 12: Responsible Consumption and Production". As a starting set, 169 indicators were listed to operationalize the SDGs, still leaving blank some important areas where indicators would have to be established. A field of particular relevance is the tracking of 
impacts of national activities on foreign countries. This article will focus on the possibilities to monitor various "footprints" of countries' production and consumption on the environment in other regions, or globally.

The implementation of SDGs at the national level and the further development of the set of indicators continues and takes place in a dynamic process, which depends on the national priorities, the possibilities of data collection and reporting, and not least on further research and development activities to improve the knowledge base and monitoring.

The main advantage of the SDG concept is an internationally comparable set of indicators, for which the data basis in major parts already exists. For a country like Germany for example, in addition to the global perspective, the targets at the EU level as well as the national level have to be considered. In order to assess the progress of the SDG's at the national level with implications for the global effects, it is necessary to define indicators in the prioritized areas.

This article develops a comprehensive framework for the evaluation of the sustainability of the bio-economy, considering key objectives and relevant criteria for environmental, economic, and social sustainability and the respective evaluation criteria.

\section{Material and Methods}

\subsection{The Driving forces-Pressure-State-Impact-Response Concept}

The Driving forces-Pressure-State-Impact-Response (DPSIR) concept was developed in the 1990s [39]. The core of the concept is socio-economic drivers like production, consumption, and the construction and maintenance of infrastructure. These exert pressures to the environment by extraction and harvest of raw materials, and final disposal of waste and release of emissions to water and air. As a consequence, the state of environmental changes impacts society and environmental systems, with consequences such as climate change and biodiversity losses. The reaction to this takes place in the form of policies, and society in the form of a regulatory influence on drivers, pressures, and impacts. Since an effective reduction of environmental impacts is primarily achieved through technical or organizational measures along the production-consumption chain, the focus is set purposely on the regulatory impact on these causal drivers (production, final consumption, and infrastructure).

The resource inputs determine the extent of material throughput in the production and consumption system, and thereby have a direct impact on the scale of the environmental impacts associated with extraction or harvest (input), and emission or waste (output). In addition to the resources used, the direct and indirect use of cropland area by the production and consumption system is another important stress factor. A schematic DPSIR system, taken from and subsequently adapted and supplemented by Bringezu et al. [40], is shown in the supplementary information (Figure S1).

\subsection{Requirements for Indicators of Sustainability}

Indicators are measured variables which provide empirical statements on the facts to be described in a representative form [41].The choice of indicators included should be made in a way that they initially provide sufficiently valid information about the respective target question. In our case, they ought to highlight progress and regression in relation to essential aspects of a sustainable bio-economy. The scope of the indicator set has a direct relationship to the nature of the statement. A small number reduces the level of detail of the statement and is more appropriate to provide overview, while a large number of indicators reduces the overview character of the statement and is more appropriate to elucidate details. In order to ensure the required level of quality of information, it is necessary to define certain guideline, indicators in a set of indicators must meet. These guidelines vary according to different authors and institutions, depending on the underlying question. The following requirements have been listed most frequently: scheduled and quantified targets, robustness, communicability, vertical integration, coherence, and data availability [42-44]. We conclude that a key set of sustainability indicators should be tested against the listed characteristics before application. Some indicators, which 
are relevant to measure progress on the macro level, can also be applied on a product level, for instance, by means of life-cycle assessment (LCA) [45]. Indicators for social LCA [46] follow, in principle, the same framework.

\subsection{Definition of Key Objectives for the Three Pillars of Sustainability}

The three-pillar model of sustainability [47] was used as systemic basis for the assignment of key objectives to the categories of ecological sustainability, economic sustainability, and social sustainability. In this article, the term "environmental sustainability" is used instead of "ecological sustainability". A distinction is made between specific and integrative key objectives. The specific key objectives are pillar-specific, such as the key objective of working conditions for the pillar of social sustainability. Integrative key objectives can be assigned to at least two pillars at the same time, and thus lie within the intersection areas of the columns.

In Germany, in the course of preparing a research program to underpin a monitoring system of the bioeconomy, three status reports about the "existing basics and contributions for a monitoring of the bioeconomy" were published by Adler et al. [48], Delzeit et al. [49], and O'Brien et al. [50]. Adler et al. carried out comprehensive literature research on the subject of the key objectives of bio-economy, which includes strategy papers of the Federal Ministry of Education and Research [2] and the Federal Ministry of Food and Agriculture [51], as well as scientific papers. As with the SDGs, the progress reports formulate objectives and indicators for assessing progress in increasing the sustainability of production and lifestyles. It pointed out that there is a need for development, particularly with regard to the recording and modelling of resource footprints. However, their results only refer to the three pillars of sustainability in a separate way.

In this paper, the assessment is extended by key objectives assigned to the intersection areas of the three pillar concept. Here, the results of Zeug et al. [52] are reflected, who identified priority issues for monitoring of bio-economy under sustainability aspects through a stakeholder survey. A text-analytical comparison of the Agenda 2030 with strategy papers on the bio-economy of the EU and the German government revealed complementary priorities. While the United Nations puts the avoidance of hunger and the development of developing countries first, for the Federal Government and the EU, the (socio-) economic and technical-innovative potentials of the bio-economy have a higher priority. The survey of stakeholders from the fields of business, NGOs, and science, in turn, revealed a comprehensive German perspective, in which the international impacts of national action were brought to the fore. The global fight against hunger has also been identified as a particular priority by stakeholders, which in the field of bio-economy means that food production should be given preference over the production of non-food products ("food first").The development of sustainable consumption and production structures was also classified as a particular priority. The protection of biodiversity in terrestrial and aquatic ecosystems was also considered particularly important, as was the maintenance of good water quality.

\subsection{Resource and Climate Footprint Concepts in the Current Literature}

In the current scientific literature discussing life-cycle impacts of countries, the term "footprint" is commonly used. Various teams of researchers have already dealt with one or more footprint concepts [53-57]. The supplementary information (Table S1) provides an overview of the leading footprint concepts and their main authors. The following sections describe the concepts of the different resource footprints referring to Bringezu et al. [40]. A viable data base for footprint calculations are input-output tables [58]. Different multi-regional input-output tables were established and evaluated for footprint analysis within the last several years. Examples are EORA [59], GTAP [60], and EXIOBASE [61]. These tables are quantifying the product flows between industries and consuming sectors, both within and between countries, and their environmental extensions include extraction of resources, emissions, and final waste disposal. As a consequence, product groups consumed in one country can be traced back to their origin in other countries and regions. Depending on the calculation method, the result is 
either the footprint of production (domestic extraction + import) or the footprint of final consumption (domestic production + import - export), including upstream resource requirements or greenhouse gas emissions.

\subsubsection{Agricultural Land Footprint}

The main categories of land use are urban and infrastructure areas, agricultural areas, forest areas, areas for nature conservation, and others, including water bodies.

The expansion of urban (settlement) area and agricultural area at the expense of forest area is an important driver of global land use change (LUC). In Germany, the expansion of urban area on productive and fertile agricultural land is the most important factor for LUC. Furthermore, the expansion and intensification of the use of existing agricultural land worldwide leads, in many cases, to soil degradation [30]. These described influences in combination with an increasing world population and a hereby-increasing demand for food make agricultural land an even more valuable resource.

The agricultural land footprint consisting of cropland and land for permanent cultures and perennial plants is of great importance for the implementation of the global key objective of "halting the loss of biodiversity through the expansion of agricultural area".

The agricultural land footprint of domestic production is calculated from the share of domestic arable land and the share of arable land in foreign countries, which is indirectly used for domestic consumption via the import of products. If the amount of land under cultivation for export products is deducted from this footprint, the footprint of domestic consumption results.

The unit of the agricultural land footprint is hectares per person. This enables an international comparison, as well as a relation to reference values of the sustainably available areas. Data on the global use of agricultural and forestland at national level are provided in annual reports by the Food and Agricultural Organization of the United Nations (FAO). The analysis of agricultural land footprints is the subject of various publications, e.g., by $\mathrm{O}^{\prime}$ Brien et al. [62].

\subsubsection{Forest Footprint}

The forest footprint (FFP) is calculated from the quantity of domestic primary timber harvested annually, plus the quantity of primary timber used abroad for the production and processing of products, indirectly used by domestic players through the import of these products. If the amount of primary timber used for export products is deducted from this footprint of production, the FFP of domestic consumption results.

The FFP is thematically assigned to the material footprint. However, its valuation is based on a different reference unit and a specific valuation scale. The data basis of the FFP can be taken from the biotic fraction of the raw material input (RMI).

The FFP is evaluated by comparing it with the net annual increment (NAI) of a reference area (country, EU, international) and the orientation value of the sustainable use of forest resources [63]. Approximate values of the NAI at the country level can be taken, for example, from O'Brien [63]. The unit of the NAI is ( $\left.\mathrm{m}^{3} /\left(\mathrm{a}^{*} \mathrm{ha}\right)\right)$. This corresponds to the unit cubic meter of standing stock. The NAI is used as a common parameter in wood statistics, such as the results database of the Federal Forest Inventory [64].

The steady increase in the use of forest resources underlines the importance of calculating and evaluating an FFP. The amount of timber used in the paper and cardboard sector has risen sharply over the last 50 years. Although the majority of this is already being made available through waste paper recycling, the use of primary timber is increasing worldwide [63]. Global timber production is forecast to increase by $44 \%$ between 2005 and $2030[65,66]$, pointing to a sharp increase in the demand for forest biomass for final energy production, as used in the IPCC scenarios, for example. The evaluated FFP provides answers to the question of whether the forecasted timber demand can be satisfied under a sustainability perspective. 


\subsubsection{Water Footprint}

The concept of the Water Footprint (WFP) was developed by Hoekstra and Hung [67] and supplemented over the years. The Water Footprint Assessment Manual, published in 2011, describes three types of water footprints [68].

The blue WFP refers to the amount of extracted surface or groundwater.

The green WFP comprises the quantities of precipitation water released into the atmosphere during the growing period (or lifetime) of a crop by evapotranspiration of the plant and evaporation of the soil.

The grey WFP corresponds to the dilution volume required to dilute anthropogenically released pollutants into surface and groundwater bodies, to a concentration defined by specific threshold values.

Meanwhile, the effects of indirect water use must be taken into account, as the use of regional water resources is no longer spatially tied to a respective consumer due to global product flows. This has led to a series of concepts for concretizing and evaluating the water footprint, which are constantly being further developed.

Of particular note is DIN EN ISO 14046:2016-07 (Environmental Management-Water FootprintPrinciples, Requirements, and Guidelines), which aims to ensure international consistency in the determination and reporting of water footprints. In these new concepts, the water footprints according to Hoekstra et al. [68] are each referred to as the virtual water content of a product and weighted by using various criteria. An important criterion is the availability or scarcity of water in the region where a certain (agricultural) product is produced. The "Water Scarcity Index" (WSI), according to Pfister et al. [69], is an example. The direct, and especially the indirect, use of water through product exports can thus be evaluated and discussed against the background of the water supply in a region.

In total, $70 \%$ of the world's fresh water is used for irrigation of crops [70]. The progressive expansion of irrigated areas contributes to the regional scarcity of water reserves worldwide [71,72].

Therefore, a focus of the water footprint survey can be set on water abstraction for irrigation of crops, represented by the blue WFP.

The green WFP of an unirrigated area results from the amount of precipitation minus the surface runoff and minus the drainage through the root zone (groundwater runoff). It can be calculated as evapotranspiration of a plant. When assessing the effects of water use on regional water reserves, the green WFP has no significance for unirrigated areas, as it does not represent anthropogenic water abstraction, and the exclusive use of green water in crop production therefore does not contribute to water scarcity.

For an irrigated area, the proportion of (blue) irrigation water and (green) precipitation water in evapotranspiration can only be broken down with the aid of special models, whose calculations are prone to errors due to necessary simplifications and uncertainties, and are therefore under criticism [73]. A breakdown is necessary for the correct calculation of the green WFP, because since the here applied concept is mapping the entire abstraction of blue water for irrigation via the blue WFP, any loss of blue water as a result of extraction (e.g., also by evaporation) is already taken into account.

Green WFPs are also insignificant when it comes to changing water quality through anthropogenic use, as green water is purified from its material load by evaporation. Green WFPs play a role in the assessment of land use changes and their effect on surface and groundwater runoff. Since most agricultural systems return less precipitation to the atmosphere through evapotranspiration than the natural systems they replace, global runoff in river systems has increased by about 7\% [70].

Further research is needed for a satisfactory concept for the grey WFP that meets the requirements.

\subsubsection{Material Footprint}

The Material Footprint (MFP) of a product can be determined by the cumulative raw material input, according to VDI 4800 Part 2. It covers the resource input associated with the production, use, recycling, and disposal of biotic and abiotic raw materials. The cumulative raw material input is methodologically rather similar to the Raw Material Input (RMI) introduced at national and EU level [74-76]. The only 
difference is that the latter accounts biomass harvest from agriculture and professional gardening, while the former regards those processes as within the economy, which requires recalculating that biomass into their abiotic inputs.

The MFP of domestic production (Raw Material Input, RMI) is calculated from the total domestic extraction of raw materials and the quantity of raw materials used abroad for the production and processing of products, which is indirectly used by domestic producers via the import of these products. When the quantity of raw materials used for export products is deducted from the RMI, the MFP of domestic consumption is obtained (Raw Material Consumption, RMC).

A separate identification of abiotic and biotic raw materials, both part of RMI and RMC, is possible. Abiotic raw materials include ores, fossil fuels, and non-metallic minerals, while biotic raw materials include agricultural, forest, and aquatic raw materials. The category $\mathrm{RMI}_{\text {biotic }}$ includes food as well as biomass used for material and energy purposes.

As material flows induced by the economy and society, and thus also their effects on the environment, are expected to increase worldwide in the coming decades [77], the monitoring of the material footprint is of great value in the sense of a global increase in sustainability. Sufficient data is also available on an international level. The data basis for the collection of the material footprint are international input-output tables, as contained among others in the IRP database. International comparisons of material footprints are provided by the UNEP [78,79].

However, the calculation of these raw material indicators does not take into account the unused part of the extraction. Total extraction, covering both used and unused extraction, would be accounted for by the indicators Total Material Requirement, TMR, and Total Material Consumption, TMC [74,80]. An update on the global scale is necessary since the data basis is still in an early stage of development.

\subsubsection{Climate Footprint}

The Climate Footprint (CFP) cumulates the direct and indirect greenhouse gas emissions of all processes associated with a product or service over the entire life cycle of a product or service. For a country, it is usually accounted for on a yearly basis. Indirect greenhouse gas emissions refer to the emissions that must be allocated to the region of consumption via the import and export of products from the region of production, processing, or the like. The climate footprint of domestic production and consumption is calculated analogously to the footprints described above.

The CFP is established as an environmental impact indicator in the LCIA and has been part of many studies [81-85].

The IPCC lists a lot of different gases which react climate-actively [86]. Six of these gases are mentioned in the Kyoto Protocol: $\mathrm{CO}_{2}, \mathrm{CH}_{4}, \mathrm{~N}_{2} \mathrm{O}, \mathrm{HFC}, \mathrm{PFC}$, and $\mathrm{SF}_{6}$ [87]. Later, $\mathrm{NF}_{3}$ was added to the list [88].

\section{Result Analysis}

\subsection{Key Objectives of the Bioeconomy}

The key objectives of the social, economic, and environmental sustainability, with the intersections between the different pillars, are presented in Figure 1. The aspects food security, sustainable final consumption, sustainable production, and sustainable infrastructures could be identified as integrative key objectives. The integrative character of these four key objectives results from the fact that they are relevant to all three pillars of sustainability. The indicator system presented here will therefore take particular account of these aspects. The results of Zeug et al. [52] support the importance of those integrative key objectives for German stakeholders. 


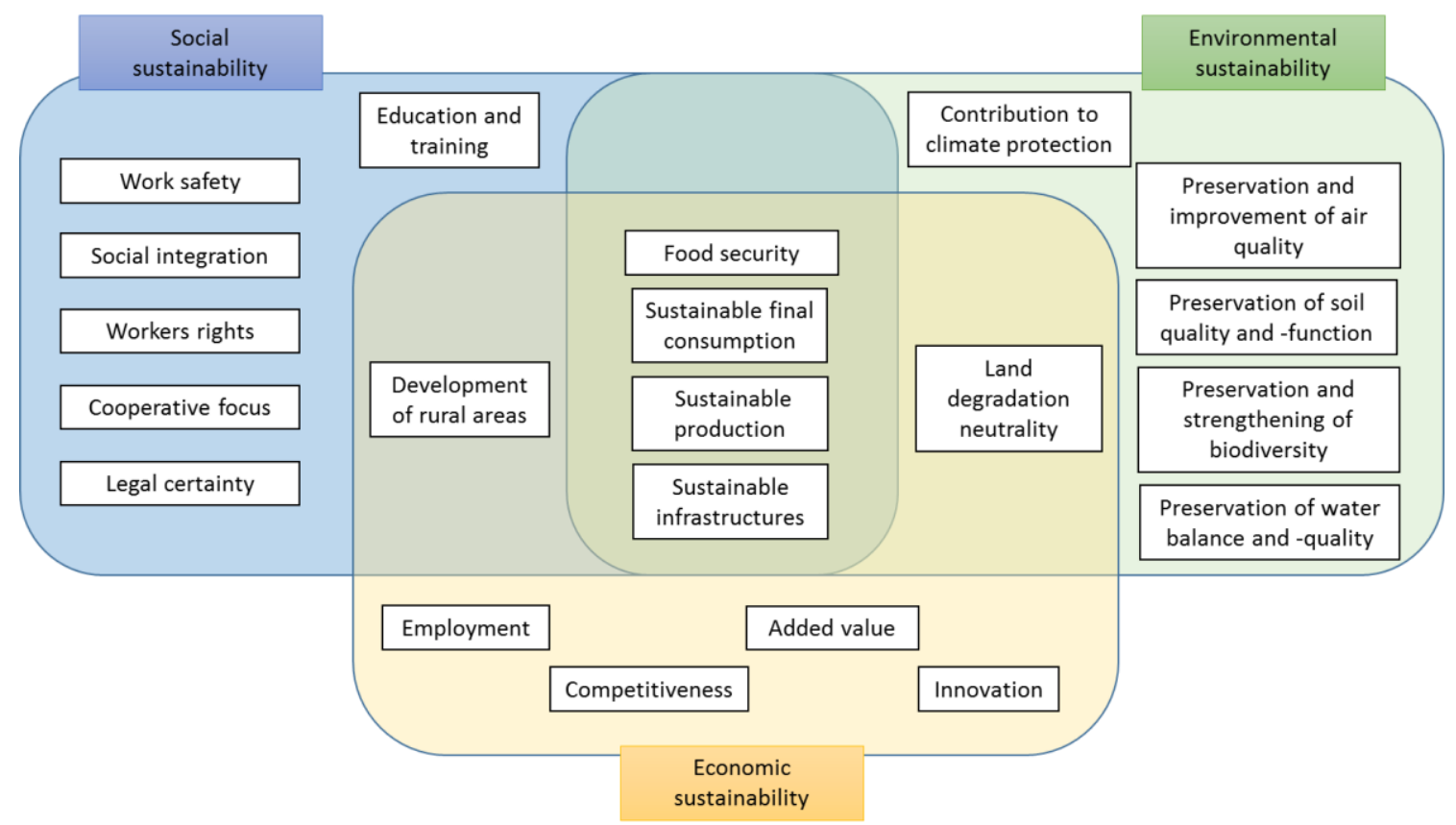

Figure 1. Key objectives of the bioeconomy.

\subsection{Information Aggregation and Levels of Action}

The three pillars of sustainability-environment, economy, and society-define the basis for the thematic framework of the indicator system. Each of the three pillars has assigned key objectives. An adequate set of indicators is necessary to quantify the key objectives. The supplementary information (Tables S2-S4) show an overview about the key objectives and assigned indicators of the three pillars.

It is part of an information pyramid, from which three levels of information aggregation are picked out, which correspond to the base, the middle, and the top of the pyramid, in which one may observe continuous transitions. The top form the headline indicators, followed by the specific indicators, and the base forms the basic data (Figure 2).
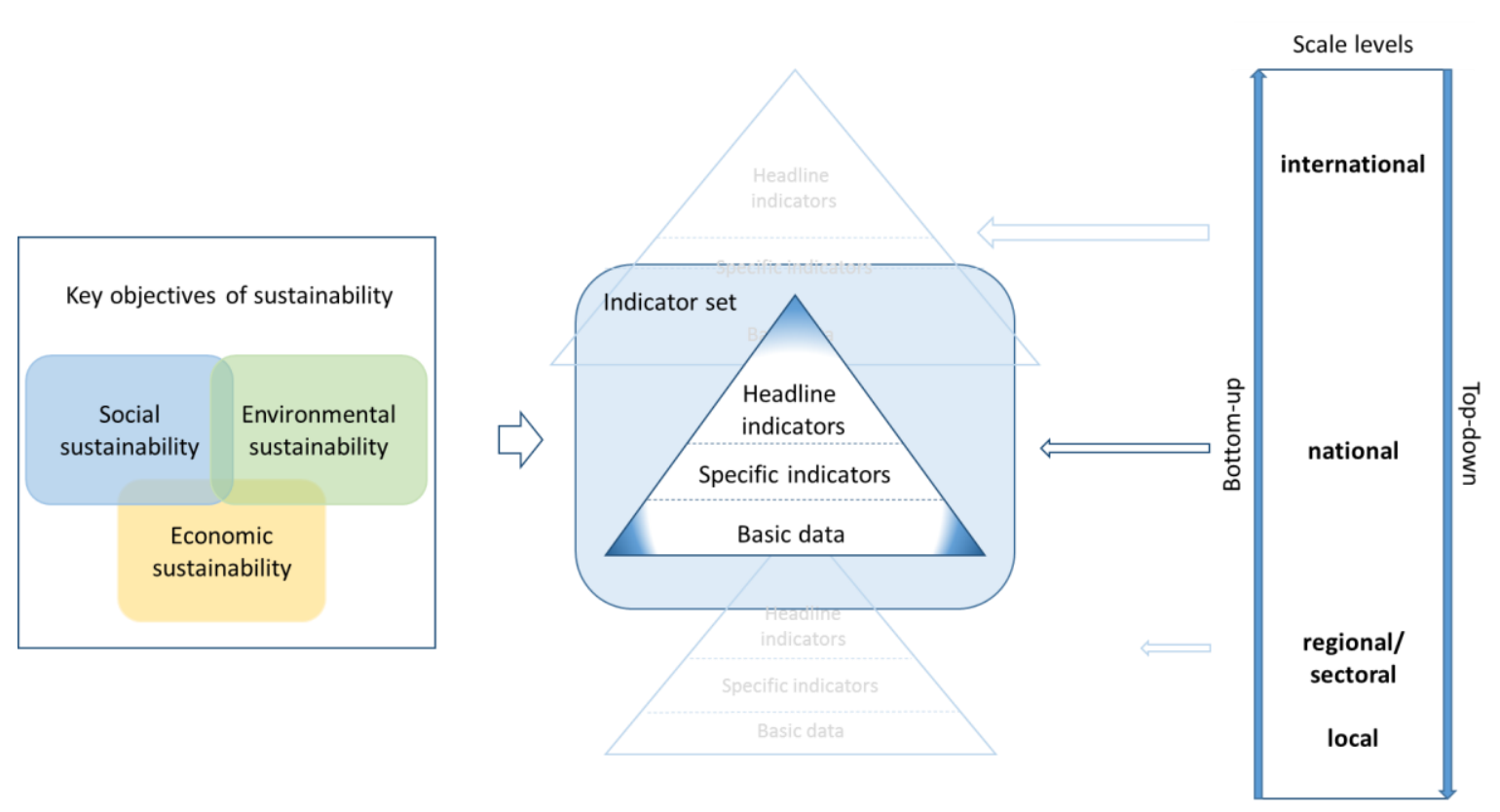

Figure 2. Aggregation, scale levels, and information flow of the indicator system. 
Headline indicators summarize certain aspects in a clear form so the cause-effect relationships can be bundled by them. Headline indicators should inform about essential characteristics of a system. Combined with reference values, they indicate to decision-makers the need for change measures. They therefore have a high degree of aggregation of information and a correspondingly low level of detail. In this paper, the headline indicators include resource footprints, which are used to measure important integrative key objectives of sustainability (part of several pillars). An example for a well-known economic headline indicator is GDP (gross domestic product).

Specific indicators broaden and deepen the information the headline indicators provide. They are defined more narrowly but still keep the attributes of an indicator, meaning they adequately inform about certain characteristic features. An example would be the indicator of self-sufficiency in forest resources. In the social sector, an example indicator could be the level of disabled persons integrated in the bioeconomy (e.g., workshops for disabled people). On the lowest level of the information pyramid, basic data provide information. These are used to calculate specific and headline indicators. Basic data can be partly used their own characteristic values and have a high degree of detail. The aggregation of information provided by the different layers of the information pyramid has to be distinguished from the scaling level of actors and the respective monitoring. Here the range of actors extends from a local level, regional and national level, up to the global level. Each of the scale levels has to be monitored considering different information pyramids. Depending on the local conditions, the headline indicators of the different information pyramids may differ.

Significant for the presented indicator system is the multi-scale applicability and relevance. The consideration of all pillars of sustainability for the derivation of the indicator framework guarantees a holistic point of view. It hereby enables users to answer target questions on sustainable development from a large-scale international level to a small-scale regional level of action. The underlying target question defines the level of observation. It is decisive that goals on the national level can only be realized if the necessary information is forwarded and monitored on lower levels of action. Vice versa, substantial requirements and development of local and regional levels has to be considered in the goals, the evaluation criteria, and the monitoring on a higher level of scale. A top-down as well as a bottom-up information flow is necessary to realize an adequate information flow within the system.

\subsection{Integrative Key Objectives of the Bioeconomy}

The cross-dimensional key objectives are particularly important, not least because of their integrative character (Figure 1, Table 1). The selection of key objectives and criteria was conducted following Section 2.3 of the article. We assigned an exemplary indicator to each criterion. Regarding the FAO food security indicators, an internationally well-established set of indicators is chosen. The second set of headline indictors are the resource footprints; there relevance is further explained below. Criteria that are also explicitly mentioned in the subject catalogue of the SDGs are listed separately, stating the respective number. Aspects marked with an asterisk $\left({ }^{*}\right)$ were classified as particularly relevant in the stakeholder analysis reported by Zeug et al. [52]. Classical LCA indicators are listed, e.g. climate footprint, as well as indicators which can be assigned to social LCA [46], like the indicator of political stability within the FAO food security indicators.

Indicators marked with (") are not part of regular data collection, but refer to the results of individual reports. The last column shows possible sources of data for the indicator quantification. LandSHIFT is a land use change model for global and regional scale simulation experiments developed by Schaldach et al. [89] at the Center for Environmental Systems Research (CESR) in Kassel. 
Table 1. Integrative key objectives, criteria, and indicators of sustainability.

\begin{tabular}{|c|c|c|c|c|}
\hline Integrative Key Objectives & Criteria & Sustainable Development Goal (SDG) & Headline Indicators/Specific Indicators & Scale Levels/Sources \\
\hline \multirow{3}{*}{ Development of rural areas (RA) } & Working conditions in the RA & $9.1,11.2$ & Access to public transport in RA & national [90] \\
\hline & Employment in the RA & $(8.5)$ & Number of employees in RA in Full Time Equivalents (FTE) & national [90] \\
\hline & Added value in the RA & (9.3) & Added value of the selected bio-economy sectors in the RA & national [90] \\
\hline \multirow{6}{*}{ Land degradation neutrality } & Land consumption & $2.4,14.5,15.1$ & Ratio of land use categories to total land area & national/EU/international [91] \\
\hline & Land consumption & $2.4,15.3$ & Proportion of degraded agricultural area & international [92] \\
\hline & & $2.4,15.3$ & Loss of agricultural area & national/EU/international [91] \\
\hline & Land use change (LUC) & $15.1,15.2,15.3$ & Loss of forest area & national/EU/international [91] \\
\hline & Indirect land use change (iLUC) & - & Loss of agricultural area & national/EU/international [91] \\
\hline & 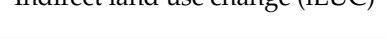 & - & Loss of forest area & national/EU/international [91] \\
\hline \multirow{3}{*}{ Food security* } & Food situation & 2. & FAO Indicators for food security & international [92] \\
\hline & Price development & 2.c & Development of consumer prices for food commodities & $\begin{array}{c}\text { national [90], } \\
\text { EU [93] } \\
\text { international [92] }\end{array}$ \\
\hline & Self-sufficiency rate & - & Share of food consumption covered by domestic production & national [94] \\
\hline \multirow{9}{*}{$\begin{array}{l}\text { sustainable } \\
\text { Production* } \\
\text { Infrastructures* } \\
\text { Final consumption* }\end{array}$} & & - & (Agricultural-) land footprint & - \\
\hline & & - & Forest footprint & - \\
\hline & Resource inputs and & - & Water footprint & - \\
\hline & & - & Climate footprint & - \\
\hline & & $8.4,12.2$ & Material footprint & international [95] \\
\hline & Resource productivity & 12.2 & $\begin{array}{l}\text { Total raw material productivity } \\
\text { (GDP per resource consumption) }\end{array}$ & national/EU [93] \\
\hline & Waste management & $\begin{array}{l}11.6,12.3,12.5 \\
12.5\end{array}$ & $\begin{array}{c}\text { Amount of waste } \\
\text { Recycling rate of municipal waste }\end{array}$ & national [90] \\
\hline & Production cascades & - & Biomass utilization factor & national [96] \\
\hline & Certification & - & $\begin{array}{l}\text { Share of products certified for } \\
\text { sustainable production in final consumption }\end{array}$ & national [97] \\
\hline
\end{tabular}


The table does not claim to be complete, but serves to illustrate an exemplary structure of an indicator system for assessing the sustainability of the bioeconomy. The respective indicator table may need to be adapted depending on the national or regional conditions, policy priorities and the scale of the reference system. Selected indicators would need to be checked against the quality criteria described in Section 2.2 before application.

Rural development is a key objective that can be assigned to both social and economic sustainability assessments through the spatially differentiated presentation of criteria, such as working conditions, employment, and added value.

Another important key objective is the avoidance of area degradation in the sense of Land degradation neutrality [98-101]. Meaning that settlement areas, for example, do not expand indefinitely at the expense of agricultural areas, and these in turn do not expand at the expense of forest and natural areas. Land degradation neutrality aims at a zero net balance of change between the types of land use. For monitoring, in the first step, the real domestic land use is presented, divided into the five main categories of land use: settlement and transport areas, cropland, forest areas, water areas, and other areas, such as protected areas (nature reserves, national parks, and biosphere reserves). In a second step, criteria will have to be applied which aim at direct and indirect land-use changes (LUC and iLUC) associated with activities within national territory, impacting land use on foreign territory, in particular losses of agricultural and forest land. These data are determined in connection with the quantification of area footprints, since the indirectly induced losses are used to determine the land use triggered by the product demand of domestic consumption abroad. In the land use category of arable land, it must also be examined to what extent parts of it are degraded, e.g., by erosion.

Food security is a key objective that is becoming increasingly important as the world's population is growing. Therefore, food security has the highest priority within the bioeconomy. In order to guarantee this, criteria from all three pillars must be examined and observed. These include price trends, the nutritional situation, and self-sufficiency. Indicators such as the trend in consumer prices for food, the proportion of food consumption that can be covered by domestic production, and the FAO indicators for food security can be assigned to them. The latter are divided into four different categories, which are shown in the supplementary information (Table S5).

An important goal of bioeconomy is to strengthen sustainability in production, infrastructure, and consumption [77]. German stakeholders attach particular importance to this goal [52].

In order to meet this expectation, it is necessary to extend the indicator set of SDGs in a way that it is possible to make sufficient statements on the criteria of resource inputs, consumption, and efficiency. Currently, German official reporting only considers the material intensity, putting the material footprint in relation to an economic output indicator. In order to be able to make statements about the total resource requirements and key environmental pressures, it is also necessary to determine the resource footprints for (agricultural) land, forest, and water, and the climate footprint in terms of greenhouse gases (GHG). The resource and climate footprints of domestic consumption relate to the extent to which resources are used or GHG emissions are released on national and foreign territory, in connection with the final domestic consumption of products. The quantity of these resources, used for imports or emissions released for their production abroad, is added to the annual domestic resource use and emissions by production, processing, etc., and the quantities of the resource used or emissions released for exporting these products are deducted.

While sustainable production and consumption are related to SDG 12 "Responsible consumption and production", the integrative key objective of sustainable infrastructure relates explicitly to SDG 9.1 "Build resilient infrastructure, promote inclusive and sustainable industrialization and foster innovation". In this goal, the development of "quality, reliable, sustainable, and resilient infrastructure ... to support economic development and human well-being" is demanded, which states the integrative character of this key objective.

In addition to the use of resources, resource productivity is another important criterion in order to assess the performance of bioeconomy. Indicators of resource productivity are raw material 
productivity (GDP/cost of raw materials) $(€ / \mathrm{kg})$ and area productivity (yield/reference area) $(\mathrm{t} / \mathrm{ha})$. At the country level, reference area may refer to the domestic area under cultivation (for specific crops), or the footprint area.

Waste management has a direct influence on the sustainability of production, consumption, and infrastructure. Indicators, such as the amount of waste or the recycling rate of municipal waste, allow drawing conclusions about the resource losses occurring in the system, and thus provide indications of possible optimizations. The criterion use of production cascades is directly related to this, since the use of primary resources can be reduced by the multiple use of a product. According to the definition of the Federal Environment Agency, cascade use exists if the end product of a production process from biogenic raw material to bio-based product is used for material or energy purposes, at least a second time [102]. This is quantified by the indicator biomass utilization factor.

Certification is a criterion that can have a beneficial impact on the sustainability of bioeconomy if two aspects are fulfilled. On the one hand, the respective certificate must scientifically substantiate an increase in the sustainability of the respective production-consumption chain. On the other hand, the consumer must trust the respective certificate and consequently change or adapt his consumer behavior. The core aspect is to increase the transparency of the life cycle of products for end consumers. From an overall economic perspective, the share of products certified for sustainable production in final consumption can be a possible indicator.

The aspect of good political practice (good governance), which is addressed in the SDG's catalogue by the sub item 16 peace, justice and strong institutions, would formally belong to the category of integrative key objectives. However, this key objective is not specifically relevant for the bioeconomy as such, and is therefore not included in Table 1. Nevertheless, good political practice can be important for assessing the origin of imports.

\subsection{Resource Footprints as Indicators for the Integrative Key Objectives}

In two decades of life cycle impact assessment (LCIA) and research on environmental impact categories, like the greenhouse effect, a number of methodical approaches have been developed to depict further specific environmental impacts of products system-wide (eutrophication, ozone depletion, ozone formation, acidification potential, ecotoxic potential, etc.). However, to quantify the various mid- and end-point indicators of LCIA for specific products, a high degree of spatial differentiation is often needed, and while there has been progress towards this end in recent years [16], still no global widely-accepted methodology or comprehensive database exists [45].

The level of detail of the resource footprints in comparison to the numerous indicators used in LCIA may appear superficial. Steinmann et al. [56] proved that the four resource footprints of material, water, fossil energy, and land combined represent more than $84 \%$ of the variance of all product specific environmental impacts investigated in product life cycle assessment. They are, therefore, a good proxy for environmental damage potential [103].

This leads to the hypothesis that in order to produce an overall picture on a global perspective, "the abundance of environmental indicators can be reduced to a small key set, which represents the major part of the change of environmental influences between product life cycles" [56].

The authors take up this approach here. Figure 3 illustrates the direct relation of resource footprints as indicators of the integrative key objectives of the bioeconomy. In contrast to Steinmann et al. [56], in this approach the indicator climate footprint is used instead of the cumulated fossil primary energy, in order to include greenhouse gases such as methane and nitrous oxide, which play an important role in agricultural processes. Additionally, based on Bringezu et al. [12], the authors introduce a forest footprint for the quantification of the use of forest biomass induced by the bioeconomy.

The five footprints are determined in their scale by the volume of material throughput of the production and consumption system, which in turn determines the extent of impact bundles associated with resource extraction, product use, and disposal. The footprints provide highly aggregated information on key performance properties of the (bio-)economy and related environmental impact 
potential. In the future, they may be further combined with more specific information of impact cascades in the environment, when more product specific information on production-consumption chains and spatially explicit data on impacts become available.

A consumption perspective on social indicators helps to reveal trade-related impacts of social responsibility issues [104]. Comparing eleven social indicators and seven environmental footprints for specific countries, O'Neill et al. [105] found out that none of these countries meet basic social needs without crossing biophysical boundaries (following the planetary boundaries concept [106]). Therefore, in the future, it will be interesting to monitor not only the resource footprints of nations but also related social aspects, e.g., on the social implications in the exporting countries supplying products to net consuming countries.

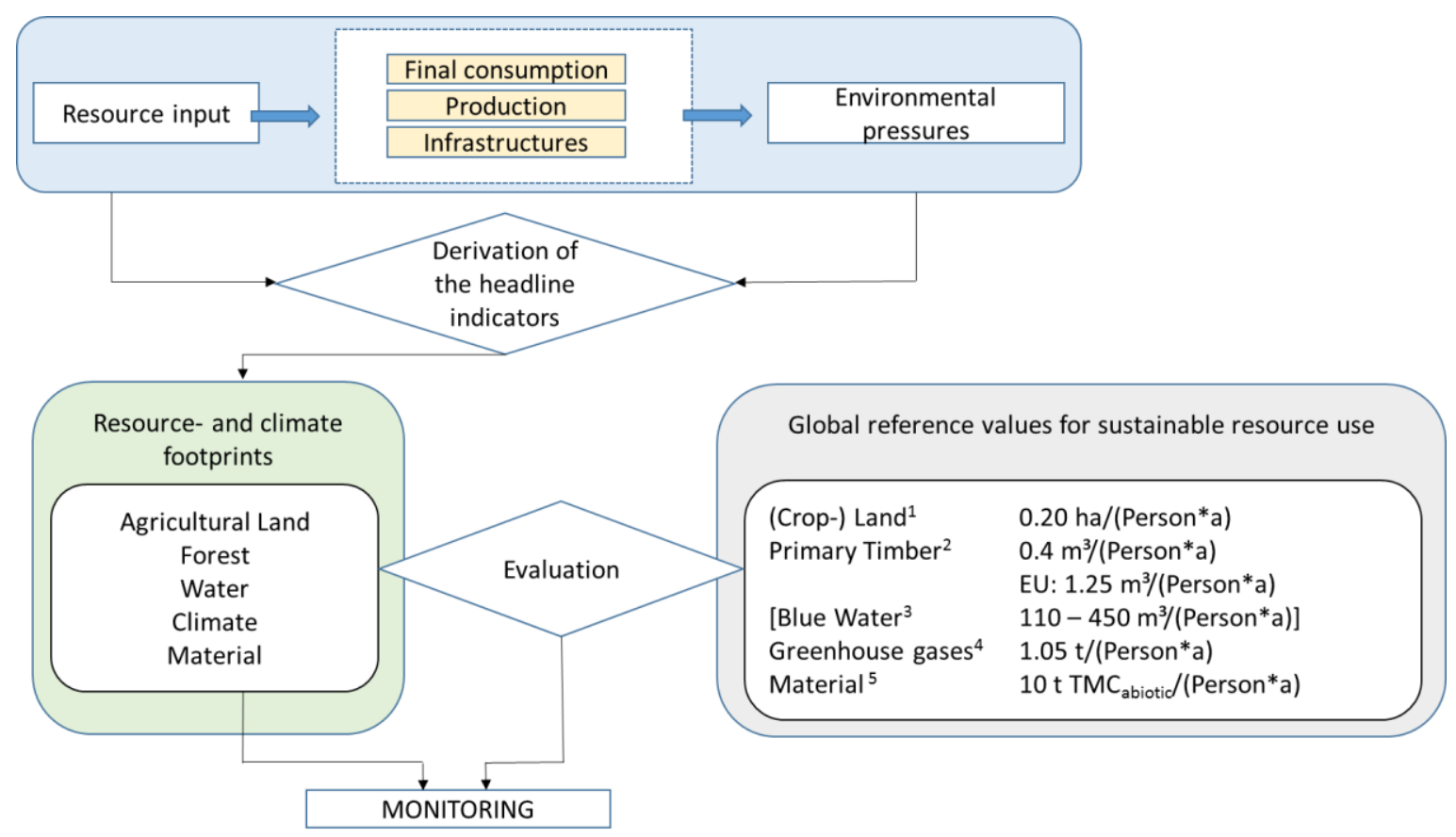

Figure 3. Resource footprints as headline indicators of the key objectives of bioeconomy. The reference values of sustainable resource use are taken from the following sources: ${ }^{1}[12],{ }^{2}[63],{ }^{3}[107]$ based on [108], ${ }^{4}[109],{ }^{5}$ This material footprint focuses on abiotic materials. $\mathrm{TMC}_{\text {abiotic }}$ is only relevant for the consideration of bioeconomy to the extent that problem shifts into mineral-based raw material areas are to be expected.

\subsection{Evaluation of the Resource Footprints based on Sustainability Criteria}

However, the quantification of a resource footprint does not allow statements about the change in sustainability performance. Therefore, it is necessary to put the respective footprint in relation to orientation values in a meaningful reference system (global, regional, local). A table showing the reference values of sustainable resource use of water, materials, primary timber, carbon, and cropland, which is taken and amended from O'Brien et al. [110], is provided in the supplementary information (Table S6).

These orientation values consider, on the one hand, objects of protection, like the global biodiversity, and on the other hand respect the criteria of international equity, in which each person is in principle granted the same right to use resources (expressed by per-person values).

For example, Bringezu et al. [12] suggested to use 0.20 hectares per person as an orientation value for the cropland area available to produce finally consumed agricultural goods under sustainability criteria in 2030. This calculation was based on the assumption that the Business-as-Usual development of the cropland expansion will be stopped after 2020. The resulting value of 1.66 billion hectares under cultivation was related to the world population in 2030. The problem that the global expansion of 
agricultural land is a major driver of biodiversity loss is particularly important in the sustainability assessment $[16,17,111]$. The convention of biological diversity (CBD) already has the status of an international treaty. If their goal of halting the loss of global biodiversity is to be achieved, this requires, in particular, a halt to the net expansion of agricultural land, especially intensively used arable land.

In 2007, each EU citizen consumed an average of 0.31 hectare of global arable land through the consumption of agricultural products [12]. As a consequence, consumption of agricultural products would have to be reduced or adjusted, resulting in a reduction of about $35 \%$ in the area needed to achieve this orientation value (e.g., by reducing the consumption of animal products, as feed production contributes significantly to the area footprint).

To what extent a global average value for the use of water make sense is debatable because the availability and scarcity of water resources are distributed very differently around the globe. The current use of blue water is still below the orientation value shown in Figure 3, which could lead to the impression that there would be no serious problem. At the level of catchment, however, there are regions where blue water is so heavily overused that the load limits of the regional system have been reached, which raises risks for people and the environment [71,112]. In order to also measure regional water scarcity, Steffen et al. [106] extended their concept and defined a second control variable at catchment level as a percentage of the withdrawal of blue water from the average monthly quantity of water in rivers. Their limit is between $25 \%$ and $85 \%$, depending on the size of the flow.

\section{Conclusions}

The system of indicators for assessing the sustainability of the bioeconomy presented here outlines the key objectives necessary for a holistic view, and assigns criteria and indicators to them. Although all three pillars-environment, economy, and society—are, per se, relevant for sustainability assessment, this working paper focuses on the integrative key objectives and assigned indicators, for which there is still a need for development. The high relevance of these aspects was also emphasized in the stakeholder analysis by Zeug et al. [52]. The scale of the consumption of natural resources and GHG emissions determines the bundle of environmental impacts caused by human activities at the national and foreign territory level. The footprint indicators (agricultural land, forest, water, material, and climate) are instrumental in quantifying the resource and climate impact of the production and consumption system, and to highlighting the share the bioeconomy has.

Agricultural biomass is increasingly being used for material and energy purposes. The associated competition for land to produce food has triggered a scientific and social discussion about food security, price developments, and ecological effects, such as changes in land use. It is necessary to monitor the material and energetic use of agricultural biomass as an essential part of the bioeconomy. An important criterion for improving sustainability within the bioeconomy is land use change, which goes hand in hand with the increasing demand for biomass.

The predicted increase in the use of forest biomass for material and energy recovery by the middle of the century due to rising demand [66] might conflict with the conservation of forest ecosystem services, to a lesser extent in Germany, but to a significant degree in other world regions supplying Germany. The increase in raw timber imports to Germany in recent years is documented, for example, by Weimar [113]. Further research is required to assess the interdependency of the domestic demand for forest biomass with the development of the energy sector, as it is described in the scenarios of Buongiorno et al. [66]. These include the consequences of energy and climate policy objectives.

These considerations and exemplary presentations should help to improve the reference basis for the analysis, modeling, and evaluation of bioeconomy with regard to its sustainability. It is foreseeable that neither the goals, nor the indicator systems and their evaluation criteria and measures will ever have reached a final status, since this will change with the development of the issues, with learning and perspectives. The growing level of knowledge supports the need for continuous further development of the indicator system and its evaluation criteria. 
Supplementary Materials: The following are available online at http://www.mdpi.com/2071-1050/11/2/443/s1, Figure S1: DPSIR System-Schematic interdependency of resource use and environmental impacts; Table S1: Overview of resource footprint concepts and authors in the current scientific literature; Table S2: Key objectives, criteria, and indicators of social sustainability; Table S3: Key objectives, criteria, and indicators of economic sustainability; Table S4: Key objectives, criteria, and indicators of environmental sustainability; Table S5: FAOFood Security Indicators; Table S6: Reference values of sustainable resource use.

Author Contributions: V.E. prepared the article including research, assessment, and writing. S.B. provided support across all phases and supervised, edited, and commented on the article.

Funding: This work was conducted within the scope of the projects BEPASO (Bio Economy PAthways and SOcietal transformation strategies) and SYMOBIO (SYstemic MOnitoring and modelling of the German BIOeconomy), funded by the Federal Ministry of Education and Research (BMBF).

Acknowledgments: The authors like to thank the colleagues at the Center for Environmental Systems Research (CESR) in Kassel for their comments and suggestions, which improved the manuscript.

Conflicts of Interest: The authors declare no conflict of interest.

\section{References}

1. Bioökonomierat Was IST Bioökonomie? Available online: biooekonomierat.de/biooekonomie/ (accessed on 6 November 2018).

2. Bundesministerium für Bildung und Forschung (BMBF). Nationale Forschungsstrategie BioÖkonomie 2030Unser Weg zu Einer Bio-Basierten Wirtschaft; BMBF: Berlin, Germany, 2010.

3. Bundesministerium für Ernährung und Landwirtschaft (BMEL) Nationale Politikstrategie Bioökonomie. Nachwachsende Ressourcen und Biotechnologische Verfahren als Basis für Ernährung, Industrie und Energie; BMEL: Berlin, Germany, 2014.

4. Bundesministerium für Ernährung und Landwirtschaft (BMEL) Fortschrittsbericht zur Nationalen Politikstrategie Bioökonomie; BMEL: Berlin, Germany, 2016.

5. Hüsing, B.; Kulicke, M.; Wydra, S.; Stahlecker, T.; Aichinger, H.; Meyer, N. Evaluation der Nationalen Forschungsstrategie BioÖkonomie 2030_Kurzfassung; BMBF: Berlin, Germany, 2017.

6. Bundesministerium für Bildung und Forschung (BMBF). Pressemitteilung: 096/2018. Available online: https://www.bmbf.de/de/mit-vereinter-kraft-fuer-die-biooekonomie-5782.html (accessed on 12 December 2018).

7. Patermann, C.; Aguilar, A. The origins of the bioeconomy in the European Union. New Biotechnol. 2018, 40, 20-24. [CrossRef] [PubMed]

8. European Commission. Review of the 2012 European Bioeconomy Strategy; European Commission: Brussels, Belgium, 2017.

9. European Commission. Roadmap: Update of the 2012 Bioeconomy Strategy; European Commission: Brussels, Belgium, 2018.

10. European Comission. A Sustainable Bioeconomy for Europe: Strengthening the Connection between Economy, Society and the Environment. Updated Bioeconomy Strategy; European Commission: Brussels, Belgium, 2018.

11. Mengal, P.; Wubbolts, M.; Zika, E.; Ruiz, A.; Brigitta, D.; Pieniadz, A.; Black, S. Bio-based Industries Joint Undertaking: The catalyst for sustainable bio-based economic growth in Europe. New Biotechnol. 2018, 40, 31-39. [CrossRef]

12. Bringezu, S.; O’Brien, M.; Schütz, H. Beyond biofuels: Assessing global land use for domestic consumption of biomass. A conceptual and empirical contribution to sustainable management of global resources. Land Use Policy 2012, 29, 224-232. [CrossRef]

13. Bruckner, M.; Giljum, S.; Fischer, G.; Tramberend, S.; van Velthuizen, H.; Wunder, S.; Kaphengst, T.; McFarland, K. Extending Land Footprints towards Characterizing Sustainability of Land Use; Umweltbundesamt: Dessau-Roßlau, Germany, 2017.

14. Fischer, G.; Tramberend, S.; Bruckner, M.; Lieber, M. Quantifying the Land Footprint of Germany and the EU Using a Hybrid Accounting Model; Umweltbundesamt: Dessau-Roßlau, Germany, 2017.

15. De Baan, L.; Alkemade, R.; Koellner, T. Land use impacts on biodiversity in LCA: A global approach. Int. J. Life Cycle Assess. 2013, 18, 1216-1230. [CrossRef]

16. Chaudhary, A.; Pfister, S.; Hellweg, S. Spatially Explicit Analysis of Biodiversity Loss Due to Global Agriculture, Pasture and Forest Land Use from a Producer and Consumer Perspective. Environ. Sci. Technol. 2016, 50, 3928-3936. [CrossRef] [PubMed] 
17. Wilting, H.C.; Schipper, A.M.; Bakkenes, M.; Meijer, J.R.; Huijbregts, M.A.J. Quantifying Biodiversity Losses Due to Human Consumption: A Global-Scale Footprint Analysis. Environ. Sci. Technol. 2017, 51, 3298-3306. [CrossRef] [PubMed]

18. EEA. EU Bioenergy Potential from a Resource-Efficiency Perspective; European Environment Agency: Copenhagen, Denmark, 2013.

19. De Schutter, L.; Giljum, S. A Calculation of the EU Bioenergy Land Footprint Discussion Paper on Land Use Related to EU Bioenergy; Commissioned by Friends of the Earth Europe: Vienna, Austria, 2014.

20. Lapola, D.M.; Schaldach, R.; Alcamo, J.; Bondeau, A.; Koch, J.; Koelking, C.; Priess, J.A. Indirect land-use changes can overcome carbon savings from biofuels in Brazil. Proc. Natl. Acad. Sci. USA 2010, 107, 3388-3393. [CrossRef] [PubMed]

21. Lambin, E.F.; Meyfroidt, P. Global land use change, economic globalization, and the looming land scarcity. Proc. Natl. Acad. Sci. USA 2011, 108, 3465-3472. [CrossRef]

22. Bird, D.N.; Zanchi, G.; Pena, N. A method for estimating the indirect land use change from bioenergy activities based on the supply and demand of agricultural-based energy. Biomass Bioenergy 2013, 59, 3-15. [CrossRef]

23. Meyfroidt, P.; Lambin, E.F.; Erb, K.H.; Hertel, T.W. Globalization of land use: Distant drivers of land change and geographic displacement of land use. Curr. Opin. Environ. Sustain. 2013, 5, 438-444. [CrossRef]

24. Noble, I.; Bolin, B.; Ravindranath, N.H.; Verardo, D.J.; Dokken, D.J. Land Use, Land Use Change, and Forestry; Cambridge University Press: Cambridge, UK, 2000.

25. Allwood, J.M.; Bosetti, V.; Dubash, N.K.; Gómez-Echeverri, L.; von Stechow, C. Glossary. In Climate Change 2014: Mitigation of Climate Change; Cambridge University Press: Cambridge, UK, 2014.

26. Weber, C.; Matthews, H. Food-Miles and the Relative Climate Impacts of Food Choices in the United States. Environ. Sci. Technol. 2008, 42, 3508-3513. [CrossRef] [PubMed]

27. Haberl, H.; Erb, K.-H.; Krausmann, F.; Berecz, S.; Ludwiczek, N.; Martínez-Alier, J.; Musel, A.; Schaffartzik, A. Using embodied HANPP to analyze teleconnections in the global land system: Conceptual considerations. Geogr. Tidsskr. J. Geogr. 2009, 109, 119-130. [CrossRef]

28. Erb, K.H.; Krausmann, F.; Lucht, W.; Haberl, H. Embodied HANPP: Mapping the spatial disconnect between global biomass production and consumption. Ecol. Econ. 2009, 69, 328-334. [CrossRef]

29. Schaller, S.; Vogell, K.; Georgi, R.; Kuhndt, M.; Raab, C. Nachhaltigkeit in der Deutschen KonsumgüterwirtschaftThemen, Trends und Initiativen; Germany GmbH Maarweg: Köln, Germany, 2012.

30. UNEP; Bringezu, S.; Schütz, H.; Pengue, W.; O’Brien, M.; Garcia, F.; Sims, R.; Howarth, R.; Kauppi, L.; Swilling, M.; Herrick, J. Assessing Global Land Use: Balancing Consumption with Sustainable Supply; International Resource Panel Working-Working Group on Land and Soils Lead; United Nations Environment Programme: Nairobi, Kenya, 2014.

31. Ronzon, T.; M'Barek, R. Socioeconomic Indicators to Monitor the EU's Bioeconomy in Transition. Sustainability 2018, 10, 1745. [CrossRef]

32. Joint Research Center. Life Cycle Indicators for Resources, Products and Waste; Joint Research Center: Ispra, Italy, 2012.

33. FAO (Food and Agriculture Organization) Sustainable Bioeconomy Guidelines. Available online: http: //www.fao.org/energy/bioeconomy/en/ (accessed on 18 December 2018).

34. Dubois, O.; Gomez San Juan, M. How Sustainability Is Addressed in Official Bioeconomy Strategies at International, National and Regional Levels-An Overview; FAO: Rome, Italy, 2016.

35. UN. Transforming Our World: The 2030 Agenda for Sustainable Development; UN: New York, NY, USA, 2015.

36. UN. The Sustainable Development Goals Report; UN: New York, NY, USA, 2017.

37. Statistisches Bundesamt. Statistisches Bundesamt Indikatoren der UN-Nachhaltigkeitsziele; Statistisches Bundesamt: Wiesbaden, Germany, 2017.

38. European Commission. EU SDG Indicator Set; European Commission: Brussels, Belgium, 2017.

39. Smeets, E.; Weterings, R. Environmental Indicators: Typology and Overview; European Environment Agency: Copenhagen, Denmark, 1999.

40. Bringezu, S.; Potocnik, J.; Schandl, H.; Lu, Y.; Ramaswami, A.; Swilling, M.; Suh, S. Multi-scale governance of sustainable natural resource use-Challenges and opportunities for monitoring and institutional development at the national and global level. Sustainability 2016, 8, 778. [CrossRef]

41. OECD. OECD Environmental Indicators: Development, Measurement and Use; OECD: Paris, France, 2003; Volume 25. 
42. Schostock, D. Nachhaltigkeitsindikatoren auf EU, Bundes- und Länderebene-eine Übersicht; Wuppertal Institute: Wuppertal, Germany, 2015.

43. Sustainable Development Solutions Network (SDSN). Indicators and a Monitoring Framework for Sustainable Development Goals_Launching a Data Revolution; SDSN: Paris, France; New York, NY, USA, 2015.

44. European Commission. EU SDG Indicator Set 2018 Result of the Review in Preparation of the 2018 Edition of the Eu Sdg Monitoring Report; European Commission: Brussels, Belgium, 2018.

45. UNEP/SETAC. Global Guidance for Life Cycle Impact Assessment Indicators_Volume 1; 1st ed.; United Nations Environment Programme: Paris, France, 2016; ISBN 978-92-807-3630-4.

46. UNEP/SETAC. Guidelines for Social Life Cycle Assessment of Products; United Nations Environment Programme: Paris, France, 2009; Volume 15.

47. Enquete-Kommission. Schutz des Menschen und der Umwelt. In Abschlußbericht der Enquete-Kommission "Schutz des Menschen und der Umwelt"-Ziele und Rahmenbedingungen Einer Nachhaltig Zukunftsverträglichen Entwicklung"; Enquete-Kommission: Bonn, Germany, 1998.

48. Adler, P.; Budzinski, M.; Erdmann, G.; Majer, S.; Meisel, K.; Schock, S.; Thrän, D. Sachstandsbericht über Vorhandene Grundlagen und Beiträge für ein Monitoring der Bioökonomie: Nachhaltigkeit und Ressourcenbasis der Bioökonomie; Wuppertal Institute: Leipzig, Germany, 2015.

49. Delzeit, R.; Klepper, G.; Söder, M. Sachstandsbericht über Vorhandene Grundlagen und Beiträge für ein Monitoring der Bioökonomie: Wirtschaftliche Kennzahlen; Wuppertal Institute: Kiel, Germany, 2015.

50. O'Brien, M.; Dietmar, W.; Stefan, B.; Arnold, K. Sachstandsbericht über Vorhandene Grundlagen und Beiträge für ein Monitoring der Bioökonomie: Systemische Betrachtung und Modellierung der Bioökonomie; Wuppertal Institute: Wuppertal, Germany, 2015.

51. Bundesministerium für Bildung und Forschung (BMBF); Bundesministerium für Ernährung und Landwirtschaft (BMEL). Bioökonomie in Deutschland. Chancen für eine Biobasierte und Nachhaltige Zukunft; BMBF: Berlin, Germany, 2014.

52. Zeug, W.; Bezama, A.; Moesenfechtel, U.; Jähkel, A.; Thrän, D. Stakeholder's Interests and Perceptions of Bioeconomy Monitoring-Using an SDGs Framework. 2019; in preparation.

53. Čuček, L.; Klemes, J.J.; Kravanja, Z. A review of footprint analysis tools for monitoring impacts on sustainability. J. Clean. Prod. 2012, 34, 9-20. [CrossRef]

54. Galli, A.; Wiedmann, T.; Ercin, E.; Knoblauch, D.; Giljum, S. Integrating Ecological, Carbon and Water Footprint: Defining the "Footprint Family" and Its Application in Tracking Human Pressure on the Planet; Open-EU: Vienna, Austria, 2011.

55. Giljum, S.; Lutter, S.; Bruckner, M.; Aparcana, S. State-of-Play of National Consumption-Based Indicators-A Review and Evaluation of Available Methods and Data to Calculate Footprint-Type (Consumption-Based) Indicators for Materials, Water, Land and Carbon; Open-EU: Vienna, Austria, 2013.

56. Steinmann, Z.J.N.; Schipper, A.M.; Hauck, M.; Huijbregts, M.A.J. How Many Environmental Impact Indicators Are Needed in the Evaluation of Product Life Cycles?-Supporting Information. Environ. Sci. Technol. 2016, 50, 3913-3919. [CrossRef] [PubMed]

57. Tukker, A.; Bulavskaya, T.; Giljum, S.; De Koning, A.; Lutter, S.; Simas, M.; Stadler, K.; Wood, R. Environmental and resource footprints in a global context: Europe's structural deficit in resource endowments. Glob. Environ. Chang. 2016, 40, 171-181. [CrossRef]

58. Tukker, A.; Giljum, S.; Wood, R. Recent Progress in Assessment of Resource Efficiency and Environmental Impacts Embodied in Trade: An Introduction to this Special Issue. J. Ind. Ecol. 2018, 22, 489-501. [CrossRef]

59. Lenzen, M.; Kanemoto, K.; Moran, D.; Geschke, A. Mapping the structure of the world economy. Environ. Sci. Technol. 2012, 46, 8374-8381. [CrossRef]

60. Peters, G.P.; Andrew, R.; Lennox, J. Constructing an environmentallyextended multi-regional input-output table using the gtap database. Econ. Syst. Res. 2011, 23, 131-152. [CrossRef]

61. Stadler, K.; Wood, R.; Bulavskaya, T.; Södersten, C.J.; Simas, M.; Schmidt, S.; Usubiaga, A.; Acosta-Fernández, J.; Kuenen, J.; Bruckner, M.; et al. EXIOBASE 3: Developing a Time Series of Detailed Environmentally Extended Multi-Regional Input-Output Tables. J. Ind. Ecol. 2018, 22, 502-515. [CrossRef]

62. O'Brien, M.; Schütz, H.; Bringezu, S. The land footprint of the EU bioeconomy: Monitoring tools, gaps and needs. Land Use Policy 2015, 47, 235-246. [CrossRef]

63. O'Brien, M. Timber Consumption and Sustainable Forest Use; Kassel University Press: Kassel, Germany, 2016; ISBN 9783737601504. 
64. Bundesministerium für Ernährung und Landwirtschaft (BMEL). Der Wald in Deutschland-Ausgewählte Ergebnisse der Dritten Bundeswaldinventur; BMEL: Berlin, Germany, 2014.

65. FAO. State of the World's Forests 2009; Food and Agriculture Organization of the United Nations (FAO): Rome, Italy, 2009.

66. Buongiorno, J.; Zhu, S.; Raunikar, R.; Prestemon, J. Outlook to 2060 for World Forests and Forest Industries: A Technical Document Supporting the Forest Service 2010 RPA Assessment; US Department of Agriculture Forest Service, Southern Research Station: Asheville, NC, USA, 2012.

67. Hoekstra, A.Y.; Hung, P.Q. Virtual Water Trade: A Quantification of Virtual Water Flows between Nations in Relation to International Crop Trade; UNESCO-IHE: Delft, The Netherlands, 2002.

68. Hoekstra, A.Y.; Chapagain, A.K.; Aldaya, M.M.; Mekonnen, M.M. The Water Footprint Assessment ManualSetting the Global Standard; Earthscan: London, UK; Washington, DC, USA, 2011; ISBN 9781849712798.

69. Pfister, S.; Koehler, A.; Hellweg, S. Assessing the Environmental Impact of Freshwater Consumption in Life Cycle Assessment. Environ. Sci. Technol. 2009, 43, 4098-4104. [CrossRef] [PubMed]

70. Ridoutt, B.G.; Pfister, S. A revised approach to water footprinting to make transparent the impacts of consumption and production on global freshwater scarcity. Glob. Environ. Chang. 2010, 20, 113-120. [CrossRef]

71. Alcamo, J.; Henrichs, T. Critical regions: A model-based estimation of world water resources sensitive to global changes. Aquat. Sci. 2002, 64, 352-362. [CrossRef]

72. Hoekstra, A.Y.; Mekonnen, M.M.; Chapagain, A.K.; Mathews, R.E.; Richter, B.D. Global monthly water scarcity: Blue water footprints versus blue water availability. PLoS ONE 2012, 7. [CrossRef] [PubMed]

73. Perry, C. Water footprints: Path to enlightenment, or false trail? Agric. Water Manag. 2014, 134, 119-125. [CrossRef]

74. European Communities. Economy-Wide Material Flow Accounts and Derived Indicators; European Communities: Luxembourg, Belgium, 2001.

75. OECD. Measuring Material Flows and Resource Productivity_Volume 1 The OECD Guide; OECD: Paris, France, 2008.

76. Umweltbundesamt. Die Nutzung Natürlicher Ressourcen Bericht für Deutschland 2016; Umweltbundesamt: Dessau-Roßlau, Germany, 2016.

77. Bringezu, S.; Ramaswami, A.; Schandl, H.; OBrien, M.; Pelton, R.; Acquatella, J.; Ayuk, E.T.; Shun Fung Chiu, A.; Flanegin, R.; Fry, J.; et al. Assessing Global Resource Use: A Systems Approach to Resource Efficiency and Pollution Reduction; International Resource Panel: Nairobi, Kenya, 2017.

78. UNEP. Indicators for a Resource Efficient and Green Asia and the Pacific-Measuring Progress of Sustainable Consumption And Production, Green Economy and Resource Efficiency Policies in the Asia-Pacific Region; UNEP: Paris, France, 2015.

79. UNEP. Global Material Flows and Resource Productivity—Summary for Policymakers; United Nations Environment Programme: Paris, France, 2016; ISBN 9789280735543.

80. Bringezu, S.; Schütz, H.; Steger, S.; Baudisch, J. International comparison of resource use and its relation to economic growth: The development of total material requirement, direct material inputs and hidden flows and the structure of TMR. Ecol. Econ. 2004, 51, 97-124. [CrossRef]

81. Wiedmann, T.; Minx, J.C. A definition of "carbon footprint". In C.C. Pertsova, Ecological Economics Research Trends; Nova Science Publishers: Hauppauge, NY, USA, 2008.

82. Hertwich, E.G.; Peters, G.P. Carbon footprint of nations: A global, trade-linked analysis. Environ. Sci. Technol. 2009, 43, 6414-6420. [CrossRef]

83. Giljum, S.; Burger, E.; Hinterberger, F.; Lutter, S.; Bruckner, M. A comprehensive set of resource use indicators from the micro to the macro level. Resour. Conserv. Recycl. 2011, 55, 300-308. [CrossRef]

84. Steen-Olsen, K.; Weinzettel, J.; Cranston, G.; Ercin, A.E.; Hertwich, E.G. Carbon, land, and water footprint accounts for the european union: Consumption, production, and displacements through international trade. Environ. Sci. Technol. 2012, 46, 10883-10891. [CrossRef]

85. Tukker, A.; Bulavskaya, T.; Giljum, S.; De Koning, A.; Lutter, S.; Simas, M.; Stadler, K.; Wood, R. The Global Resource Footprint of Nations. Carbon, Water, Land and Materials Embodied in Trade and Final Consumption Calculated with EXIOBASE 2.1; The Netherlands Organisation for Applied Scientific Research: Delft, The Netherlands, 2014; ISBN 9783200036376.

86. IPCC Direct Global Warming Potentials. Available online: https://www.ipcc.ch/publications_and_data/ar4/ wg1/en/ch2s2-10-2.html (accessed on 6 November 2018). 
87. Matthews, H.S.; Hendrickson, C.T.; Weber, C.L. The importance of carbon footprint estimation boundaries. Environ. Sci. Technol. 2008, 42, 5839-5842. [CrossRef] [PubMed]

88. United Nations (FCCC). Report of the Conference of the Parties 11-23 November 2013; FCCC: Warsaw, Poland, 2014.

89. Schaldach, R.; Alcamo, J.; Koch, J.; Kölking, C.; Lapola, D.M.; Schüngel, J.; Priess, J.A. An integrated approach to modelling land-use change on continental and global scales. Environ. Model. Softw. 2011, 26, 1041-1051. [CrossRef]

90. Statistisches Bundesamt (Destatis) Database. Available online: https://www.destatis.de/DE/ZahlenFakten/ Datenbanken/Datenbanken.html (accessed on 5 November 2018).

91. Center for Environmental Systems Research (CESR) LandSHIFT. Available online: https://www.uni-kassel. de/einrichtungen/en/cesr/research/projects/finished/landshift.html (accessed on 5 November 2018).

92. FAO. FAOSTAT. Available online: http://www.fao.org/faostat/en/\#data (accessed on 5 November 2018).

93. European Commission EUROSTAT. Available online: http://ec.europa.eu/eurostat/de/data/database (accessed on 5 November 2018).

94. Bundesanstalt für Landwirtschaft und Ernährung (BLE) Nationale Versorgungsbilanzen. Available online: https://datenzentrum.ble.de/versorgung/ (accessed on 5 November 2018).

95. International Resource Panel (IRP) Global Material Flows Database. Available online: http://www. resourcepanel.org/global-material-flows-database (accessed on 5 November 2018).

96. Fehrenbach, H.; Köppen, S.; Breitmayer, E.; Essel, R.; Baur, F.; Kay, S.; Wern, B.; Bienge, K.; von Geibler, J.; Kauertz, B.; et al. 2 BIOMASSEKASKADEN Mehr Ressourceneffizienz durch Stoffliche Kaskadennutzung von Biomasse—von der Theorie zur Praxis. Available online: https:/www.bmu.de/fileadmin/Daten_BMU/ Pools/Forschungsdatenbank/fkz_3713_44_100_biomassekaskaden_bf.pdf (accessed on 5 November 2018).

97. BMWI Biomassestrom-Nachhaltigkeitsverordnung (BioSt-NachVO). Available online: http://www. erneuerbare-energien.de/EE/Redaktion/DE/Standardartikel/biomassestrom_nachhaltigkeitsv.html (accessed on 5 November 2018).

98. UUNCCD. Land Degradation Neutrality Resilience At Local, National and Regional Levels; UUNCCD: Bonn, Germany, 2014.

99. Davies, J.; Gudka, M.; Laban, P.; Metternicht, G.; Alexander, S.; Hannam, I.; Welling, L.; Vasseur, L.; Siles, J.; Aguilar, L.; et al. Land Degradation Neutrality: Implications and Opportunities for Conservation; IUCN: Nairobi, Kenya, 2015.

100. Orr, B.J.; Cowie, A.L.; Castillo Sanchez, V.M.; Chasek, P.; Crossman, N.D.; Erlewein, A.; Louwagie, G.; Maron, M.; Metternicht, G.I.; Minelli, S.; et al. Scientific Conceptual Framework for Land Degradation Neutrality. A Report of the Science-Policy Interface; United Nations Convention to Combat Desertification (UNCCD): Bonn, Germany, 2017; ISBN 9789295110427.

101. Cowie, A.L.; Orr, B.J.; Castillo Sanchez, V.M.; Chasek, P.; Crossman, N.D.; Erlewein, A.; Louwagie, G.; Maron, M.; Metternicht, G.I.; Minelli, S.; et al. Land in balance: The scientific conceptual framework for Land Degradation Neutrality. Environ. Sci. Policy 2018, 79, 25-35. [CrossRef]

102. Umweltbundesamt. Biomassekaskaden, Mehr Ressourceneffizienz durch Stoffliche Kaskadennutzung von Biomassevon der Theorie zur Praxis; Umweltbundesamt: Dessau-Roßlau, Germany, 2017.

103. Steinmann, Z.J.N.; Schipper, A.M.; Hauck, M.; Giljum, S.; Wernet, G.; Huijbregts, M.A.J. Resource Footprints are Good Proxies of Environmental Damage. Environ. Sci. Technol. 2017, 51, 6360-6366. [CrossRef] [PubMed]

104. Xiao, Y.; Norris, C.B.; Lenzen, M.; Norris, G.; Murray, J. How Social Footprints of Nations Can Assist in Achieving the Sustainable Development Goals. Ecol. Econ. 2017, 135, 55-65. [CrossRef]

105. O’Neill, D.W.; Fanning, A.L.; Lamb, W.F.; Steinberger, J.K. A good life for all within planetary boundaries. Nat. Sustain. 2018, 1, 88-95. [CrossRef]

106. Steffen, W.; Richardson, K.; Rockström, J.; Cornell, E.; Fetzer, I.; Bennett, E.M.; Biggs, R.; Stephen, R.; De Vries, W.; De Wit, C.A.; et al. Planetary Boundaries: Guiding Human Development on a Changing Planet. Science 2015, 347, 1259855. [CrossRef]

107. O’Brien, M.; Wechsler, D.; Bringezu, S.; Schaldach, R. Toward a systemic monitoring of the European bioeconomy: Gaps, needs and the integration of sustainability indicators and targets for global land use. Land Use Policy 2017, 66, 162-171. [CrossRef]

108. Hoekstra, A.Y.; Wiedmann, T.O. Humanity's unsustainable environmental footprint. Science 2014, 344, 1114-1117. [CrossRef] [PubMed] 
109. Roelich, K.; Owen, A.; West, C.; David, M. OPEN: EU Scenario Quantification Report: Scenarios for a One Planet Economy; European Commission: Godalming, UK, 2011.

110. O’Brien, M.; Hartwig, F.; Schanes, K.; Kammerlander, M.; Omann, I.; Wilts, H.; Bleischwitz, R.; Jäger, J. Living within the safe operating space: A vision for a resource efficient Europe. Eur. J. Future Res. 2014, 2. [CrossRef]

111. Millenium Ecosystem Assessment. Millenium Ecosystem Assessment-Ecosystems and Human Well-Being: Synthesis; Island Press: Washington, DC, USA, 2005; ISBN 1597260401.

112. Alcamo, J.; Henrichs, T.; Rösch, T. World Water in 2025-Global Modeling and Scenario Analysis for the World Commission on Water for the 21st Century; Kassel World Water: Kassel, Germany, 2000.

113. Weimar, H. Holzbilanzen 2013 Bis 2015 für die Bundesrepublik Deutschland; Thünen Working Paper; Johann Heinrich von Thünen Institute, Federal Research Institute for Rural Areas, Forestry and Fisheries: Hamburg, Germany, 2016; Volume 57.

(C) 2019 by the authors. Licensee MDPI, Basel, Switzerland. This article is an open access article distributed under the terms and conditions of the Creative Commons Attribution (CC BY) license (http://creativecommons.org/licenses/by/4.0/). 